\title{
Growth performance and prediction of carcass production of captive javan porcupine (Hystrix javanica)
}

\author{
Wartika Rosa Farida $^{1 *}$, Andri Permata Sari ${ }^{1}$, Umar Sofyani ${ }^{1}$, and R. Lia Rahadian Amalia ${ }^{1}$ \\ ${ }^{1}$ Research Center for Biology, Indonesian Institute of Sciences, Bogor 16911, Indonesia
}

\begin{abstract}
Porcupines are unique mammals, their upper body is covered with hard hair resembling sharp cylindrical spines and belongs to the order Rodentia. It has long been used as a source of animal protein. Javan porcupine (Hystrix javanica) is an endemic animal on Java and its population is estimated to continue, due to habitat destruction, poaching, and its use without a conservation. Observations on the growth of young javan porcupines were carried out for 12 months in Small Mammal Captivity, Research Center Biology - Indonesian Institute of Sciences. This study aims to determine the growth performance of young porcupines in captivity based on number of births, namely singles, twins, and triplets. The young will be with their mother for 3 months, they will be placed in individual cages. Weighing porcupines is done once a week. The results suggest that porcupines continue grow until they are 12 months old and probably continued. The average weight gain of single born was 30.31 $\mathrm{g} /$ day; birth of twins $29.65 \mathrm{~g} /$ day, $29.72 \mathrm{~g} /$ day; and birth of triplets were $29.57 \mathrm{~g} / \mathrm{day}, 28.14 \mathrm{~g} / \mathrm{day}$, and $29.79 \mathrm{~g} /$ day. Prediction of 12-month-old porcupine carcass production for single, twins, and triplets, respectively, was $6740.86 \mathrm{~g} ; 6593.15 \mathrm{~g}$; and $6470.50 \mathrm{~g}$.
\end{abstract}

\section{Introduction}

The porcupine is the prickliest of rodents, with needle-like quills on its sides, back, and tail. The Javan porcupine (Hystix javanica) is one of the 11 species of Old World Porcupines (Family: Hystricidae). This animal is active at night, while throughout the day it stays in its nest inside the ground Nowak [1], the mating system is monogamous, and a pair becomes long-life partners and breeds several times a year [2]. In its natural habitat, porcupines like to eat tubers, rhizomes, forest fruits, leaves, young stems, roots, buds, internal stems, roots, bark, and bamboo shoots $[3,4]$.

The Javan porcupine is endemic to Indonesia, its distribution covering Java, Madura, Bali, Lombok, Sumbawa, and Flores Tanah Djampa, Rintja, and Sulawesi [5, 6]. These terrestrial animals can be found mainly in lowland areas, secondary forests, and degraded lands. Porcupines are omnivores that eat leaves, fruit and insects.

\footnotetext{
* Corresponding author: wrosafarida@gmail.com
} 
Porcupines have a role as a seed dispersal agent [7]. Hystrix is a polyestrus and the gestation period for Hystrix is about 100 to 112 days [8]. A Hystrix usually has 2 to 4 youngs per birth. Female porcupine can give birth twice a year $[9,10]$. According to Van Aarde [8], in their habitat the female porcupine gives birth to one to three young per birth, $58.8 \%$ single births, $32.1 \%$ twins, and $9.1 \%$ triplets. Although young porcupines begin to eat solid food after 2 weeks of birth, the mother porcupine still has to nurse it for 13 to 19 weeks postpartum [8]. Young porcupines will live in colonies until they reach two years of age. Before they reach the age of 2 years, they will live with their mother in the nest [9].

H. Javanica has protected status based on Minister of Environment and Forestry Regulation Number: P.92/MENLHK/SETJEN/KUM.1/8/2018, and It is currently classified as Least Concern by the IUCN Red List [11]. Although H. javanica has protected status, in reality, illegal hunting of porcupines continues to increase. People in several regions in Indonesia believe that porcupine meat and other parts of the body contain medicinal properties. Porcupines are being illegally hunted and exploited throughout their range in Indonesia facilitated by poor enforcement and legislative weakness. Porcupines are in decline due to habitat loss, retaliatory killings and uncontrolled poaching [12]. Their meat is consumed as an alternative and important source of protein in parts of their range and their quills are used for decorative purposes. Food and medicine derived from wildlife have important nutritional values especially in times of crisis, although the wildlife food often regarded as supplementary to local peoples' diet [13]. Mardiastuti, et al. [14] reported that the Javan porcupine (H. javanica) and the Malayan porcupine (H. brachyura) are used by local people in Indonesia as traditional medicine.

Based on the facts above, conservation and protection efforts for the Javan porcupine should be carried out before this animal is declared extinct. One of the efforts to save it is through captivity, namely the maintenance of wildlife outside their habitat (ex situ conservation). The use of protected wildlife should be followed by breeding efforts through captivity, so that harvesting can be carried out starting from the second generation (F2) which legally can be used commercially. Harvesting is no longer done by taking directly from nature. The purpose of this study was to observe the growth of young Javan porcupine born in captivity in the number of singles, twins, and triplets, and predicting the production of porcupines carcass at the age of 52 weeks.

\section{Materials and methods}

This experiment was conducted in the Small Mammal Captivity of The Research Center for Biology, Indonesian Institute of Sciences (LIPI), Cibinong, Bogor Regency. The material used was 6 young Javan porcupines which were born from 3 females, consisting of a single, twins, and triplets. From birth to 12 weeks of age, the young porcupines are still with their mothers in the cage. Starting at 13 weeks of age, they were separated from their mothers and placed in three individual cages, each measuring length $\mathrm{x}$ width $\mathrm{x}$ height $(2.25 \mathrm{~m} \times 2.00$ $\mathrm{m} \times 2.75 \mathrm{~m}$ ) with two layers of wire walls and a concrete floor. Single young in cage A, twins in cage $B$, and triplets in cage $C$. The feed given is tubers, vegetables, fruit, koi fish pellets as a source of protein and minerals. Feeding was carried out 2 times a day, namely at 08.30 a.m. and 04.30 p.m. The amount of feed given is about $15 \%$ of the body weight of each porcupine. Drinking water is available ad libitum. No calculation of consumption and feed conversion was carried out during the study.

The method of measuring phenotypic variables is the body live weight of the young porcupines through weighing at birth and then the young is weighed every week until the $52^{\text {nd }}$ week or 1 year old. Weighing of young was carried out in the morning at 08.00 a.m before the feed was served. Weighing youngs aged 0-12 weeks using a digital scale with a capacity of $5 \mathrm{~kg}$ with an accuracy of 1 gram, and weighing porcupines aged 13-52 weeks 
using a digital scale with a capacity of $25 \mathrm{~kg}$ with a scale of $0.1 \mathrm{~kg}$. Daily weight gain was obtained from the different between final weights with initial weight which divided with total days of experiment (gram/porcupine/day) [15]. Meanwhile, the prediction of porcupine carcass weight at the age of 52 weeks was based on the percentage of carcass weight from previous studies, which was $59.68 \%$ Farida et al. [16] multiplied by the final body weight. Carcass is the body part of livestock without head, legs, skin, digestive organs, blood and kidneys. Therefore, the components called carcass are meat (muscle), bone and fat [17].

The data obtained from the research results were analyzed descriptively by describing the data in the form of tables or curves into a sentence as well as concluding the research results obtained [18].

\section{Results and discussion}

The average temperature around the captivity during the study was $25.52^{\circ} \mathrm{C}$ (morning), $30.78^{\circ} \mathrm{C}$ (noon) and $30.11^{\circ} \mathrm{C}$ (afternoon). Average air humidity in the morning, afternoon and evening, respectively $81.83 \% ; 64.26 \%$ and $70.15 \%$. According to Bartos [2] the ideal temperature for tropical porcupines is $70-85^{\circ} \mathrm{F}$ or $21-29.4^{\circ} \mathrm{C}$. The factors of low temperature and high humidity in the morning and high temperature and low humidity during the day will affect the condition and productivity of the porcupine.

From Table 1, it can be seen that the birth weight of young Sunda porcupine ranged from $206-280 \mathrm{~g}$, the litter size did not have much effect on birth weight. Reported by Roth [19] and Van Aarde [8], individual mass at birth equaling ca. 2.1\% of mean adult female mass. Male and female neonates do not differ in body mass [8] and sex ratio at parturition does not differ from 1:1 [20]. Females average ca. 1 litter per year with a mean litter interval of 385 days. Litter size ranges from 1 to 3 , with $58.8 \%$ of litters being singletons, $32.1 \%$ twins, and the remainder triplets [8].

The porcupine's body weight continued to increase until the age of 52 weeks although there was a slight fluctuation in body weight gain. Early weaning performed at the age of 12 weeks (84 days) did not affect the increase in body weight of single, twins, or triplets, while according to Van Aarde [8] mean length of lactation in 9 females porcupines was 101 days. Next Van Aarde [21] reported Postnatal growth rates do not differ between males and females and are nearly linear for the first 20 weeks of life, reaching an asymptotic point (and presumably full adult size) at ca. 52 weeks and an average mass of $11.7 \mathrm{~kg}$. Table 1 shows the average final weight of single, twins, and triplets ranging from $10.84-11.30 \mathrm{~kg}$. Reported by Barthelmess [22], the Cape porcupine (Hystrix africaeaustralis) or South African porcupine approached the age of 20 weeks and was close to linear until it reached the asymptotic point (adult age) reaching approximately 52 weeks.

The birth weight of single, twins, and triplets varied between $206-280$ grams (Table 1). In singletons and twins, the birth weight of the young female was greater than that of the young male, on the contrary in the triplets, the birth weight of the young male was greater than that of the young female. At week 12, the young is separated or weaned from its mother. Reported by Bartos [2] young porcupine should remain with their mother in the cage for 24 - 52 weeks. Early weaning is intended so that the porcupine mother can mate and get pregnant again. In addition, based on observations in captivity, since the age of 8 weeks, the youngs have started to learn to eat solid food that is usually given to their mother and the youngs already appear strong and healthy. Early weaning did not affect the growth of young porcupines, because their body weightshould continued to increase (Table 1). Nowak [1] reported that young porcupines have the fastest growth period, which is around the age of 4-5 months, then will go up and down, and will reach adult body weight at the age of 1-2 years. 
Table 1. Body weight development of young porcupines born single, twins, and triplets

\begin{tabular}{|c|c|c|c|c|c|c|}
\hline \multirow{3}{*}{ Week } & \multicolumn{6}{|c|}{ Body weight } \\
\hline & \multirow{2}{*}{$\frac{\text { Single }}{q(\mathrm{~g})}$} & \multicolumn{2}{|c|}{ Twins } & \multicolumn{3}{|c|}{ Triplets } \\
\hline & & $\delta(g)$ & $q(\mathrm{~g})$ & $\hat{o}(\mathrm{~g})$ & q $(\mathrm{g})$ & $q(\mathrm{~g})$ \\
\hline 0 (birth) & 261 & 206 & 280 & 254 & 212 & 210 \\
\hline 1 & 388 & 325 & 430 & 292 & 323 & 279 \\
\hline 2 & 408 & 472 & 647 & 470 & 460 & 370 \\
\hline 3 & 454 & 602 & 793 & 587 & 595 & 529 \\
\hline 4 & 774 & 750 & 954 & 676 & 702 & 646 \\
\hline 5 & 903 & 879 & 1068 & 829 & 860 & 821 \\
\hline 6 & 1126 & 1016 & 1183 & 1052 & 1105 & 914 \\
\hline 7 & 1338 & 1205 & 1335 & 1176 & 1273 & 1133 \\
\hline 8 & 1497 & 1285 & 1435 & 1380 & 1352 & 1376 \\
\hline 9 & 1589 & 1439 & 1560 & 1455 & 1468 & 1384 \\
\hline 10 & 1705 & 1622 & 1719 & 1653 & 1552 & 1500 \\
\hline 11 & 2004 & 2102 & 2142 & 1826 & 1707 & 1625 \\
\hline 12 & 2339 & 2235 & 2330 & 1904 & 1915 & 1907 \\
\hline 13 & 2980 & 3140 & 3355 & 2112 & 2204 & 2211 \\
\hline 14 & 3467 & 3213 & 3620 & 2305 & 2401 & 2399 \\
\hline 15 & 3602 & 3340 & 3710 & 2462 & 2510 & 2521 \\
\hline 16 & 3877 & 3510 & 3830 & 2611 & 2778 & 2764 \\
\hline 17 & 4005 & 3550 & 3925 & 3026 & 3123 & 3017 \\
\hline 18 & 4158 & 4110 & 4035 & 3312 & 3502 & 3398 \\
\hline 19 & 4230 & 4220 & 4150 & 3616 & 3836 & 3792 \\
\hline 20 & 4369 & 4340 & 4260 & 4037 & 4200 & 4102 \\
\hline 21 & 4412 & 4355 & 4335 & 4508 & 4756 & 4613 \\
\hline 22 & 4568 & 4410 & 4400 & 4765 & 5007 & 4822 \\
\hline 23 & 4673 & 4600 & 4550 & 4839 & 5110 & 4938 \\
\hline 24 & 4788 & 4635 & 4640 & 4910 & 5204 & 5108 \\
\hline
\end{tabular}




\begin{tabular}{|c|c|c|c|c|c|c|}
\hline 25 & 4876 & 4710 & 4714 & 5132 & 5386 & 5307 \\
\hline 26 & 5075 & 4730 & 4810 & 5348 & 5501 & 5435 \\
\hline 27 & 5287 & 5170 & 5275 & 5698 & 5799 & 5797 \\
\hline 28 & 5690 & 5610 & 5740 & 6005 & 6189 & 6101 \\
\hline 29 & 6003 & 6025 & 6205 & 6414 & 6215 & 6416 \\
\hline 30 & 6668 & 6615 & 6700 & 6799 & 6304 & 6811 \\
\hline 31 & 7100 & 6985 & 7105 & 7100 & 6412 & 7069 \\
\hline 32 & 7513 & 7490 & 7595 & 7255 & 6578 & 7236 \\
\hline 33 & 7941 & 7901 & 8010 & 7430 & 6866 & 7504 \\
\hline 34 & 8337 & 8433 & 8500 & 7646 & 7005 & 7709 \\
\hline 35 & 8790 & 8965 & 9087 & 7854 & 7268 & 7942 \\
\hline 36 & 9025 & 9307 & 9305 & 8038 & 7455 & 8094 \\
\hline 37 & 9398 & 9411 & 9491 & 8224 & 7680 & 8235 \\
\hline 38 & 9506 & 9521 & 9584 & 8467 & 7897 & 8444 \\
\hline 39 & 9868 & 9651 & 10011 & 8659 & 8075 & 8652 \\
\hline 40 & 10036 & 9725 & 10206 & 8891 & 8269 & 8847 \\
\hline 41 & 10201 & 9775 & 10288 & 9065 & 8497 & 9006 \\
\hline 42 & 10365 & 9795 & 10316 & 9287 & 8723 & 9244 \\
\hline 43 & 10453 & 9823 & 10504 & 9465 & 8986 & 9406 \\
\hline 44 & 10521 & 9902 & 10527 & 9577 & 9018 & 9539 \\
\hline 45 & 10626 & 9936 & 10554 & 9605 & 9112 & 9657 \\
\hline 46 & 10707 & 9949 & 10608 & 9799 & 9268 & 9706 \\
\hline 47 & 10789 & 9973 & 10615 & 9895 & 9413 & 9968 \\
\hline 48 & 10828 & 10022 & 10691 & 10112 & 9689 & 10254 \\
\hline 49 & 10879 & 10042 & 10674 & 10487 & 9790 & 10586 \\
\hline 50 & 10901 & 10056 & 10744 & 10698 & 9824 & 10820 \\
\hline 51 & 10989 & 10610 & 10889 & 10895 & 9951 & 10915 \\
\hline 52 & 11295 & 10997 & 11098 & 11018 & 10455 & 11053 \\
\hline $\begin{array}{c}\text { Average of final } \\
\text { body weight }\end{array}$ & 11295 & \multicolumn{2}{|c|}{11047.5} & \multicolumn{3}{|c|}{10842} \\
\hline
\end{tabular}




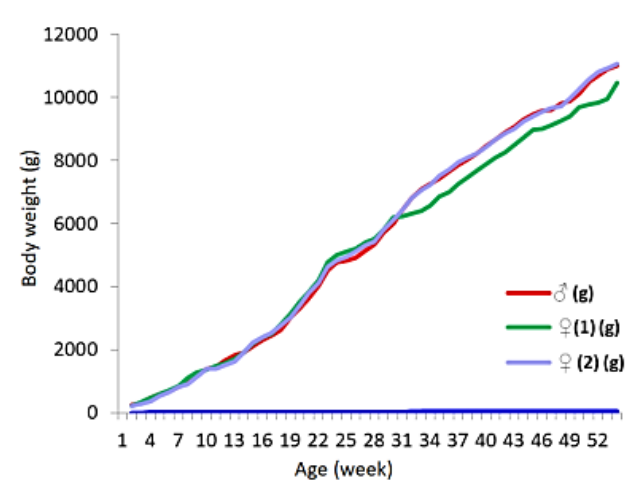

A

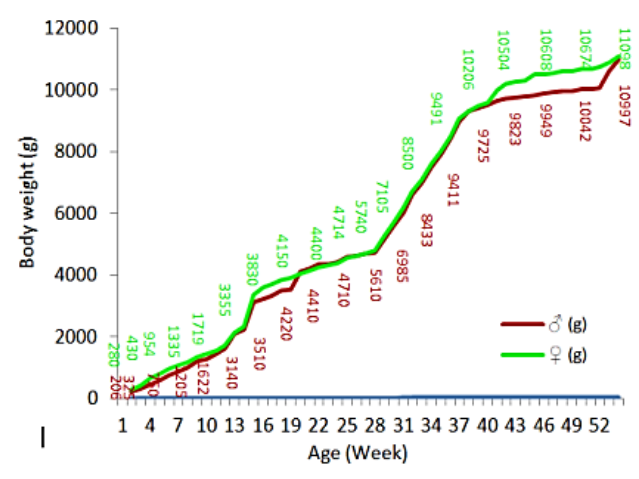

B

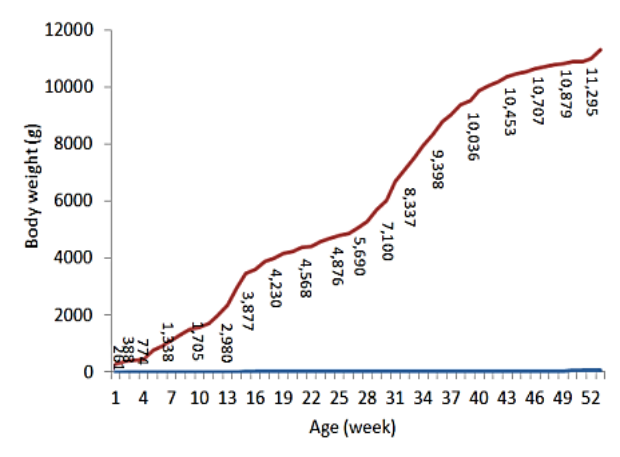

C

Fig 1. Body weight of development of sunda porcupine of litters being singletons (A), twins (B), and triplets $(\mathrm{C})$

In zootechnical studies, there are two main aspects in the growth process. The first aspect is the initial growth as an increase in body size (weight and length) per unit time, most of which have been achieved in the embryonic stage, including in the process. The second aspect is growth as a morphogenetic process, namely the increase in different body parts with changes in the size and shape of body components caused by differences in the intensity of growth of various organs and tissues. This differential growth can be called development. The part-to-whole relationship is considered stepwise, as carcass is related to live weight, major components are related to carcass weight, and individual bone, muscle, and fat depots are related to their respective total tissue weights. If animal height or weight are measured from conception to senescence, the data usually follow a flattened "S" shape called the sigmoid curve. The sigmoidal growth curve is formed because age does not cause an increase in body weight, but provides an opportunity for animals to grow, reach maturity and interact with the environment [23]. Growth initially took place very quickly (acceleration) then decreased and tended to be constant. But the growth curves of meat animals raised under commercial conditions may appear as relatively flat slopes (the middle segment of the flat "S", and the sigmoid shape may only become apparent if the data include very young animals or animal beyond a typical market weight. In other words, growth velocity is approximately constant during the commercial growing period.

From Figure 1, it can be seen that the three curves A dan B form like the letter S, while the $\mathrm{C}$ curve looks straighter because the body weight development of the three young porcupines from birth to 52 weeks of age is not much different. As reported by Von 
Bertalanffy [24], curves of animal mass growth over time are shaped in S, which is also known as sigmoid or sigmoidal curves, while according to Silva et al. [25] and Rodrigues, et al. 26] that the body growth of most animal species can be described by a sigmoid curve and, therefore, fit by nonlinear models which are widely used for a large number of regression applications. Animal development is related to metabolic rate, which directly influences mass, shape, size, and other body traits [24]. The difference in the shape of the C curve is thought to be due to the number of triplets births, so that during lactation there is competition for mother's milk and after weaning there is competition for feed. This is in accordance with Smith and Mangkoewidjojo [27], stated that adult body weight was influenced by litter size, birth weight (initial weight), mother's milk production and feeding. Cahpman [28] defined maternal effect as the influence, contribution or impact on the phenotype of an individual caused directly by the phenotype of the parent. Body weight can be influenced directly by genetic and maternal effects as well as environmental factors [29, 30,31 ]. Maternal effects on offspring phenotype can be caused by genetic or environmental differences between parents, or they can also be caused by genetic and environmental interactions. Body weight gain can be used as a variable to determine the growth of porcupines. Body weight gain is the difference between body weight (harvest) and initial body weight at a certain time. The average weight gain of porcupines for single, twins, and triplets are presented in Table 2.

Table 2. Body weight gain and prediction of carcass production of young porcupine, 1 year old (52 months)

\begin{tabular}{|c|c|c|c|c|c|c|}
\hline \multirow{2}{*}{ Item } & \multirow{2}{*}{$\begin{array}{c}\text { Single } \\
q\end{array}$} & \multicolumn{2}{|c|}{ Twins } & \multicolumn{3}{|c|}{ Triplets } \\
\hline & & $\hat{0}$ & q & $\widehat{\delta}$ & 우 & 우 \\
\hline Initial BW (g) & 261 & 206 & 280 & 254 & 212 & 210 \\
\hline Final BW (g) & 11,295 & 10,997 & 11,098 & 11,018 & 10,455 & 11,053 \\
\hline BW gain per week (g) & 212.19 & 207.52 & 208.04 & 207.00 & 196.98 & 208.52 \\
\hline BW gain per day (g) & 30.31 & 29.65 & 29.72 & 29.57 & 28.14 & 29.79 \\
\hline $\begin{array}{l}\text { Estimated carcass weight }(\mathrm{g}) \\
\text { based on carcass percentage }= \\
\left.59.68 \%^{*}\right)\end{array}$ & 6740.86 & 6563.01 & 6623.29 & 6575.54 & 6239.54 & 6596.43 \\
\hline Average carcass weight & 6740.86 & \multicolumn{2}{|c|}{6593.15} & \multicolumn{3}{|c|}{6470.50} \\
\hline
\end{tabular}

Source : Farida et al. [16]

Table 3. Slaughter weight, weight, and carcass percentage of Javan porcupine compared to other animals $\left.{ }^{*}\right)$

\begin{tabular}{|c|c|c|c|c|}
\hline Item & Sex & $\begin{array}{c}\text { Slaughter weight } \\
(\mathbf{k g})\end{array}$ & $\begin{array}{c}\text { Carcas weight } \\
(\mathbf{k g})\end{array}$ & Carcas (\%) \\
\hline Sunda porcupine & Female & 6.40 & 3.79 & 59.68 \\
\hline & Male & 8.70 & 5.16 & 59.66 \\
\hline Java mouse-deer & Female & 1.92 & 0.99 & 50.65 \\
\hline & Male & 1.53 & 0.75 & 50.48 \\
\hline Rex rabbit & Female & 3.02 & 1.54 & 51.19 \\
\hline
\end{tabular}




\begin{tabular}{|c|c|c|c|c|}
\hline & Male & 2.71 & 1.41 & 51.95 \\
\hline Goat & Female & 24.27 & 9.77 & 39.39 \\
\hline & Male & 24.23 & 11.03 & 42.48 \\
\hline Sheep & Female & 25.13 & 11.70 & 43.01 \\
\hline & Male & 25.80 & 12.53 & 44.18 \\
\hline Cattle & Female & 214.32 & 110.60 & 51.18 \\
\hline & Male & 226.14 & 115.51 & 51.02 \\
\hline
\end{tabular}

Source: Farida et al. [16]

From Table 2, it can be seen that the average daily body weight gain of porcupines were $30.31 \mathrm{~g} /$ head (single), 29.65 and $29.72 \mathrm{~g} /$ head (twins) and 29.57; 28.14; and $29.79 \mathrm{~g} / \mathrm{head}$ (triplets). Growth is generally expressed by increasing body weight and body dimensions as a reflection of the adequacy of food intake for body metabolism [32]. Table 2 shows that the average daily weight gain for single young is higher than that of twins and triplets. This is presumably because single-born get enough mother's milk intake, while twins and triplets have to compete for various milks from their mothers in the early stages of their growth. Body weight can be influenced directly by genetic and maternal effects as well as environmental factors $[29,31]$. The increase in body weight of young porcupines after being weaned from their mother will depend on the adequacy of feed and nutritional intake. The increase in body weight between male and female was not affected by birth weight, it was proven that young born with low body weights could achieve high daily body weight gain. This may be the effect of the response of the porcupine to environmental conditions such as differences in response to the feed intake. It was stated by Soeparno [33] that among individuals within a breed or between animal races there are differences in responses to the environment, including nutritional, physical, and microbiological. The difference in response causes a difference in the rate of growth. In addition, there are still similarities in the breed or type of porcupine used in this study, namely the Javan porcupine. As reported by Tillman, et al. [34], food is not the only factor influencing body composition, as breeding and sex are also strong determinants, especially when food is sufficient to support rapid growth. The same thing was also stated by Soeparno [33] also Everitt and Jury [35], that sex, hormones and castration and genotype also affect animal growth.

Increased use of the Javan porcupine for meat and medicinal purposes in some areas of Indonesia [35]. It has also increased illegal hunting and overexploitation of these animals Gomes [12]. In order to maintain the preservation of protected wild animals, through captive efforts (ex situ) namely breeding wild animals outside their habitat in a controlled manner, harvesting for commercial purposes can be carried out starting from the second generation (F2). Based on the results of research Alves et al. [13], that the percentage of porcupine carcasses was higher than that of deer, rex rabbits, goats, sheep, and cattle (Table 3 ). Prediction of carcass weight calculation of captive Javan porcupine at the age of 52 weeks, respectively $6740.86 \mathrm{~g}$ (single), $6563.01 \mathrm{~g}$ and $6623.29 \mathrm{~g}$ (twins), and 6575.54g; $6239.54 \mathrm{~g}$; and $6596.43 \mathrm{~g}$ (triplets). From the prediction of carcass weight (Table 2), singletons produced higher carcass weights than twins and triplets, while the carcass weight produced by twins was not much different from triplets.

The high carcas percentage of the Javan porcupine indicates that this animal has the potential to be bred as a meat-producing animal and can support food diversification 
programs, especially in Central Java and East Java, where most of the population has long consumed porcupines meat [35]. Porcupines are relatively undemanding to look after in captivity and acclimatise quickly to the captive environment. They become conditioned to people and are of a large enough size to make a memorable experience for captive visitors, as well as being quite engaging. They can also be used as education/outreach animals, easy to be tame, particularly if they have been hand-reared.

\section{Conclusion}

The growth curves of porcupines born single, twins, and triplets continued to increase until the observation limit of 52 weeks. Number of births, birth weight, and gender had no effect on final body weight and daily weight gain. The carcass weight of the porcupine is quite high at the age of 52 weeks, so that the porcupine has the potential to be bred as a meatproducing animal to meet protein needs and support food diversification.

\section{References}

1. R. M. Nowak, Walker's Mammals of the World, 5, 643-1629 (1991)

2. C. Bartos, Husbandry Standards for Keeping Porcupines in Captivity (Baltimore Zoo, Druid Hill Park, Baltimore, MD 21217. (1998)

3. W. R. Farida, R. Ridwan, Jurnal Biologi Indonesia, 7, 157-170 (2011)

4. A. Y. F. Khan, F. A. Asuhaimi, T. K. Jalal, F. O. Roheem, H. A. Natto, M. F. Johan, Q. U. Ahmed, R. A. Wahab, Preliminary Study Antioxid, 8, 39 (2019)

5. D. van Weers, Beaufortia, 29, 215-272 (1979)

6. H. Michael, M. McDade, D. G. Kleiman, V. Geist, Grzimek's Animal Life Encyclopedia (2004)

7. S. Timóteo, M. Correia1, S. Rodríguez-Echeverría, H. Freitas, R. Heleno, Nature Communications, 9, 140 (2018)

8. R. J. Van Aarde, Journal of Reproduction and Fertility, 75, 577-582 (1985)

9. A. H. Norsuhana, S. M. D. Nor, A. Aminah, Z. Z. Zahar, Sains Malaysiana, 38, 595600 (2009)

10. D. Lunde, K, Aplin, S, Molur, Hystrix brachyura. The IUCN Red List of Threatened Species (2016)

11. K. Aplin. Hystrix javanica. The IUCN Red List of Threatened Species (2016)

12. L. Gomez, Nature Conservation, 43, 109-122 (2021)

13. R. R. N. Alves, T. P. R. Oliveira, I. L. Rosa, Complementary and Alternative Medicine (2013)

14. A. Mardiastuti, B. Masy'ud, L.N. Ginoga, H. Sastranegara, Sutopo, Biodiversitas, 22, 329-337 (2021)

15. W. A. T. Bowker, R. G. Dumsdey, J. E. Frisch, R. A. Swan, N. M. Tulloh, Beef cattle Management and Economics (1978)

16. W. R. Farida, A. S. Tjakradidjaja, A. P. Sari, Jurnal Biologi Indonesia, 8, 381-398 (2012)

17. A. Lawrie, D. A. Ledward, Lawrie's Meat Science, 7 (2006)

18. R. G. D. Steel, J. H. Torrie, Principles and Procedures of Statistics: A Biometrical Approach, 2 (1986)

19. E, Mohr, M. Rohrs, Zeitschrif fur saugetierkunde, 313-316 (1964)

20. R. J. Van Aarde, Journal of Zoology, 213, 205-212 (1987a)

21. R. J. Van Aarde, Journal of Zoology, 211, 25-33 (1987c)

22. E. L. Barthelmess. Hystrix Africaeaustralis. Mammalian Species, 788, 1-7 (2006) 
23. H. L. Davies, A Course Manual Nutrition and Growth (1982)

24. L. Von Bertalanffy, The Quarterly Review of Biology, 32, 217-231 (1957)

25. F. de L. Silva, M. M. de Alencar, A. R. de Freitas, I. U. Packer, G. B. Mourão, Pesquisa Agropecuária Brasileira, 46, 262-271 (2011) A. Rodrigues, L. M. Chaves, F. F. Silva, I. P. Garcia, D. A. S. Duarte, H. T. Entura, Revista Ceres, 65, 24-27 (2018)

26. J. B. Smith, S. Mangkoewidjojo, Pemeliharaan, Pembiakan, dan Penggunaan Hewan Percobaan di Daerah Tropis, 1 (1988)

27. A. B. Chapman, General and Quantitative Genetics (1985)

28. E. L. Bihan-Duval, C. Berri, E. Baeza, N. Millet, C. Beaumont, Poult. Sci., 80, 839843 (2001)

29. A. N. M. Koerhuis, R. Thompson, Genetics Selection Evolution, 29, 225-249 (1997)

30. S. G. Vellemen, J. Anderson, K. E. Nestor, Poultry Science, 82, 1479-1484 (2003)

31. R. Herman, Suwartono, Kadarman, Media Peternakan, 10, 1-11 (1985)

32. Soeparno, Ilmu dan Teknologi Daging, 1 (1992)

33. A. D. H. Tillman, S. Hartadi, S. Reksohadiprojo, S. Prawirokusumo, Lebdosoekojo, Ilmu Makanan Ternak Dasar (1991)

34. G. C. Everitt, K. E. Jury, Journal of Agricultural Science, 66, 1-14 (1966)

35. W. R. Farida, Proceedings of the National Biodiversity Seminar, 2, 167-174 (2013) 